\title{
CORRIDAS DE TOROS, CULTURA Y CONSTITUCIÓN *
}

Pablo de Lora

Universidad Autónoma de Madrid

RESUMEN. En agosto de 2010 el Parlament de Catalunya aprobó la modificación de su ley de protección de los animales para abolir las corridas de toros. Aunque la prohibición afecta a ciertos derechos fundamentales y otros preceptos constitucionales relativos a la distribución competencial entre el Estado y las CC.AA., en el trabajo se defiende la constitucionalidad de priorizar la evitación del sufrimiento de los animales frente a aquellas libertades y frente a la defensa del patrimonio cultural común, que, se esgrime, corresponde al Estado.

Palabras clave: bienestar animal, Constitución, derechos fundamentales, cultura, ponderación, espectáculos públicos, libertad artística, derecho a ejercer un oficio, unidad de mercado, presunción de constitucionalidad.

ABSTRACT. In august 2010 Catalonia's Parliament banned bullfighting. In this article I defend that the ban does not contravene the Spanish Constitution. The prohibition certainly affects some constitutional provisions, including some fundamental liberties, but I claim that it is constitutionally legitimate to prioritize the purpose of avoiding animal suffering over those rights and over the defense of the common cultural heritage.

Keywords: animal welfare, Constitution, fundamental rights, culture, balance, public exhibitions, artistic freedom, right to work, market unity, constitutionality presumption.

* Fecha de recepción: 24 de mazo de 2011. Fecha de aceptación: 20 de abril de 2011. 


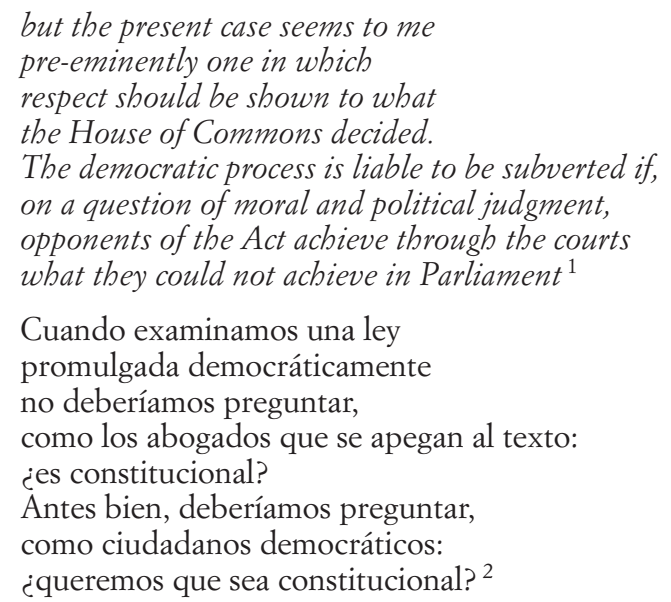

\section{INTRODUCCIÓN}

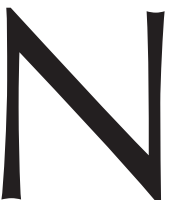

o hay rastro de los animales no humanos en la Constitución española 3 . No es extraño. Las huellas de los animales en los textos constitucionales son muy escasas. Hasta donde mis noticias alcanzan, sólo en las Constituciones nacionales de Alemania, Suiza, Angola, China, Suecia, Brasil e India se menciona, de manera más o menos directa, la protección de los animales ${ }^{4}$. Las alusiones al «medio ambiente» o a los «recursos naturales» que se encuentran en los arts. 45.1 y 45.2 de la Constitución española ${ }^{5}$ no pueden entenderse

${ }^{1}$ Opinión del juez Lord Bingham of Cornhill en $R$ (on the application of Countryside Alliance and others and others Apellants) v. Her Majesty's Attorney General and another (Respondents) (2007) UKHL 52, de 28 de noviembre de 2007 (la sentencia está disponible en http://www.publications.parliament.uk/pa/ld200708/ ldjudgmt/jd071128/countr-1.htm).

2 M. SHAPIRO, «Introduction» a The Constitution of the United States and related documents, 1968, Appleton-Century Crofts, New York (he tomado la cita de S. HolmES, «Precommitment and the Paradox of Democracy», en Constitutionalism and Democracy, J. Elster y R. SLAgSTAD, Cambridge-New York, Cambridge University Press, 1988: 195-240, 197).

3 Evitaré la constante referencia a «animales no humanos» para aludir a quienes no son miembros de la especie Homo sapiens. Utilizaré la menos técnica, pero más popular expresión «animales» a lo largo de todo el texto.

${ }^{4}$ Con la reforma de 2002, la Constitución alemana consagró la protección de los animales no humanos en el art. 20: «El Estado protegerá, teniendo en cuenta su responsabilidad por las generaciones futuras, los fundamentos naturales de la vida y los animales a través del Legislativo en el marco del orden constitucional y a través de los Poderes ejecutivo y jurisdiccional, de acuerdo con la ley y el Derecho». Es igualmente digna de destacar la enmienda constitucional que fue aprobada en el Estado de Florida por referéndum popular en noviembre de 2002 para prohibir un método de estabulación particularmente cruento de cerdas embarazadas (gestation crates). La prohibición entró en vigor en noviembre de 2008.

Para ese estudio de Derecho constitucional comparado en materia de bienestar o protección de los animales, resulta sumamente valioso el trabajo de O. LE BOT: «La protection de l'animal en droit constitutionnel. Etude de droit comparé», Lex Electronica, vol. 12, núm. 2, fall 2007 (http://www.lex-electronica.org/articles/ v12-2/lebot.htm).

5 El primero establece «el derecho a un medio ambiente adecuado para el desarrollo de la persona», y el segundo la exigencia a los poderes públicos de la utilización «racional de los recursos naturales, con el fin de proteger y mejorar la calidad de la vida y defender y restaurar el medio ambiente». Es destacable que, de acuer- 
referidas al bienestar de los animales, y, por tanto, no permiten anclar fácilmente ciertas obligaciones que pudiéramos predicar que los seres humanos tienen de no maltrato o de protección hacia los animales ${ }^{6}$.

Ello no quiere decir, por supuesto, que los tribunales constitucionales o las cortes supremas no hayan tenido que vérselas con la interpretación de las leyes que en muchísimos países, incluyendo España, se han promulgado en las últimas décadas para procurar o mejorar el bienestar de los animales. Esos problemas han sido, en ocasiones, de legalidad ordinaria ${ }^{7}$, pero en otros casos se han visto convocadas directamente cláusulas constitucionales o supraconstitucionales. Veamos algunos de ellos.

En un caso muy próximo al que será objeto de examen en estas páginas, la Corte Constitucional de Colombia tuvo que enjuiciar si era válida la excepción de las actividades taurinas, el coleo y las riñas de gallos que prevé el art. 7. ${ }^{\circ}$ de la Ley 84/1989, mediante el que se establece el «estatuto nacional de protección de los animales». El vicio de la norma radicaría en ser contraria a la prohibición de torturas y tratos crueles e inhumanos consagrada en el art. 12 de la Constitución y en la infracción del deber constitucional de cuidado de los recursos naturales y de la diversidad e integridad del medio ambiente (arts. 8, 79 y 95). Despejada la posibilidad de que la excepción contravenga el art. 12, por cuanto que ese derecho a no sufrir torturas y tratos crueles o inhumanos corresponde sólo a los seres humanos, la Corte considera que el resto de los preceptos mencionados sí limitan las opciones legislativas en cuanto a los usos y abusos de los animales. Una interpretación conforme a la Constitución de la excepción prevista en el art. 7 lleva a sostener que tales espectáculos, por su tradición y carácter artístico, deben tolerarse en las localidades donde se han venido celebrando tradicionalmente (y sólo en ellas) si se procura que los animales reciban protección contra su sufrimiento durante el espectáculo ${ }^{8}$.

do con el barómetro del CIS de mayo de 1996 (estudio 2209), el 93,2 por 100 de los españoles considera que los animales salvajes forman parte del medio ambiente, y el 82 por 100 que los animales domésticos también lo engrosan (he tomado el dato de «Ciudadanía y conciencia medioambiental en España», colección Opiniones y actitudes, núm. 67, Ángel Valencia Sáiz, Manuel Arias Maldonado y Rafael Vázquez García, CIS, 2010, 40).

${ }_{6}$ Como tuvo ocasión de afirmar el Tribunal Constitucional al resolver el recurso de inconstitucionalidad interpuesto por algunas comunidades contra la Ley 4/1989, de 27 de marzo, de Conservación de los Espacios Naturales y de la Flora y Fauna Silvestres, el ambiente «... es un concepto esencialmente antropocéntrico» (STC 102/1995, de 26 de junio, FJ 4). Vid, en la misma línea, T.-R. FERNÁNDEZ «Sobre la constitucionalidad de la prohibición de las corridas de toros en Cataluña», en este mismo número, y G. DOMÉNECH PASCUAL, «La prohibición de las corridas de toros desde una perspectiva constitucional», El cronista del Estado social y democrático de Derecho, núm. 12, 2010: 16-27, y Bienestar animal contra derechos fundamentales, Barcelona, Atelier, 2004: 80, 133-135, así como «Libertad artística y espectáculos taurino-operísticos», Revista Española de Derecho Administrativo, vol. 121, enero-marzo 2004, 92-113, 107-108.

$7 \mathrm{Si}$, por ejemplo, la producción de foie, o la lucha entre un cocodrilo y un ser humano, vulnera la normativa anticrueldad con los animales en Israel. Se trata, respectivamente de las decisiones Noab vs. The Attorney General, HCJ 9232/01 de 11 de agosto de 2003, en la que se declara que la producción de foie es contraria al Derecho israelí (se puede consultar una versión en inglés en http://elyon1.court.govil/files_eng/01/320/092/ S14/01092320.s14.pdf) y Let the Animals Live vs. Hamat Gader Recreation Industries LCA 1648/95, de 22 de junio de 1997 (conocido como «caso de los cocodrilos»), en el que se decide finalmente que el espectáculo era una forma de crueldad hacia los animales prohibida en la ley israelí de protección de los animales de 1994 (http://elyon1.court.gov.il/files_eng/96/840/016/g01/96016840.g01.pdf).

${ }^{8}$ La sentencia es la C-666/10, de 30 de agosto de 2010, y cuenta con tres votos disidentes. No era la primera vez que la Corte Constitucional colombiana se enfrentaba a la constitucionalidad de las corridas de toros. En el año 2005, mediante Sentencia C-1192/05 había declarado la constitucionalidad de la ley 916 de 2004 (de 26 de noviembre) mediante la que se establece el Reglamento Nacional Taurino. Dicha sentencia cuenta con 
El Supremo Tribunal Federal brasileño no fue tan morigerado a la hora de admitir la constitucionalidad de la tradicional «Fiesta del Buey» (farra do boi) que se celebra en el Estado de Santa Catarina: ese festejo infringe el art. 225 de la Constitución Federal $^{9}$. La Cámara de los Lores británica, por su parte, también sostuvo la prohibición de la caza del zorro establecida en la Hunting Act de 2004, pues no consideró que se vulneraran ciertos derechos del Convenio Europeo de Derechos Humanos ${ }^{10}$ ni la libre circulación de bienes y mercancías establecidas en el Tratado de la Unión Europea. Así lo ha considerado también el Tribunal Europeo de Derechos Humanos en su decisión de 24 de noviembre de $2009^{11}$.

Recientemente también, la Corte Suprema estadounidense ha tenido que determinar hasta qué punto una norma federal que castigaba hasta con cinco años de prisión la creación, venta o posesión con fines comerciales de material gráfico que muestre crueldad hacia los animales (Sección 48 de la 18 USC) es compatible con la libertad de expresión que garantiza la primera enmienda de la Constitución de los Estados Unidos ${ }^{12}$. Detrás de aquella medida estaba el intento de acabar con una industria inquietante: la de la producción de vídeos en los que se exhiben actos deliberados de maltrato y crueldad con animales indefensos para satisfacción de una cierta pulsión sexual fetichista que manifiestan algunos individuos (se trata de los denominados crush videos) ${ }^{13}$.

El caso se suscitó a raíz de la aplicación de esa norma a un distribuidor de vídeos de peleas entre animales. Una mayoría de los miembros de la Corte se inclinó por admitir la tacha de inconstitucionalidad que alegaba aquél, pues, salvo muy contadas excepciones, ha de primar siempre la libertad de expresión ${ }^{14}$. La norma es, por tanto, flagrantemente inconstitucional (facially invalid) porque, dados sus objetivos, para un número significativo de sus aplicaciones se vulnera la Constitución. En una termino-

un muy interesante y sugerente voto particular del magistrado Humberto Antonio Sierra Porto, al que luego haré referencia.

${ }^{9} \mathrm{La}$ Sentencia es de 3 de junio de 1997 (http://www.stf.jus.br/portal/jurisprudenciaTraduzida/verJurisprudenciaTraduzida.asp?tpLingua $=2 \&$ numero $=153531 \&$ classe $=R E$ ).

${ }^{10}$ Concretamente, si dicha medida atentaba contra el derecho a no sufrir interferencias por parte del poder público en la esfera privada (art. 8); el derecho de asociación (art. 11); el derecho a la propiedad privada (art. 1 del primer protocolo al Convenio) y el derecho a no ser discriminado (art. 14). La sentencia es la mencionada en la nota 1 .

${ }^{11}$ Friend and Others vs. the United Kingdom. Agradezco a G. DOMÉNECH el haberme llamado la atención sobre esta sentencia.

12 United States vs. Stevens 559 US (decidida el 20 de abril de 2010).

13 En los trabajos preparatorios en el Congreso Federal se da cuenta de que los animales empleados en esas filmaciones incluyen gatos, perros, monos, ratones y hamsters. En muchos de ellos se muestra — sin ser desvelada su identidad - a una mujer que es la que se ocupa, ataviada con los elementos propios del fetichismo sadomasoquista, de infligir la tortura. Cuando estas páginas se escriben, el diario El País informaba de cómo los grupos de activistas en defensa del bienestar de los animales se organizaban para localizar a quien, bajo el seudónimo «Asesino knino», había colgado en su blog un atroz vídeo en el que torturaba salvajemente a cachorros indefensos y amenazaba con matar a nueve más. Vid. la edición de 17 de febrero de 2011 (http://www.elpais. com/articulo/sociedad/Red/caza/torturador/cachorros/elpepusoc/20110217elpepusoc_8/Tes).

${ }_{14}$ Así, en ciertas ocasiones se han podido identificar tipos de discurso fuera del alcance de la enmienda: aquellos de escaso valor pero que generan un muy alto sacrificio del interés social y la moralidad. Es el caso de la pornografía infantil en el que hay una conexión directa e intrínseca entre el delito indudable del abuso y violación de menores, y el mercado de imágenes que muestran tales delitos. «Tal vez —afirma el magistrado Roberts- hay tipos de expresión que han estado históricamente desprotegidos pero que aún no se han identificado o discutido como tales en nuestro sistema. Pero si eso es así, no hay evidencia alguna de que entre ellas se encuentre la "exhibición de crueldad animal"». 
logía popularizada por F. SCHAUER, siendo admisible el propósito del legislador, éste habría promulgado una norma «suprainclusiva». Como alega el recurrente, la gran mayoría del material fílmico que cae bajo su alcance versa sobre actividades cotidianas plenamente legales, en las que se muestran animales «heridos o sacrificados». De otro lado, la exigencia que la norma establece de la «ilegalidad» del acto no es siempre equivalente a un comportamiento cruel: la muerte de animales protegidos por normas que tratan de evitar su extinción es ilegal, pero no hay necesariamente crueldad de por medio ${ }^{15}$.

Otra de las dificultades para acoger la constitucionalidad de la norma tiene que ver con las divergencias que se dan entre los Estados en materia de legislación anticrueldad. Hay una evidente falta de consenso sobre lo que constituye o no maltrato a los animales. El único requisito en cuanto al carácter ilegal del comportamiento con los animales es que así se tipifique en alguno de los 50 Estados de la Federación, allí donde la creación, venta o posesión del material tiene lugar. En el Distrito de Columbia toda caza es ilegal, y sin embargo no es así en otras jurisdicciones. ¿Es por tanto ilegal vender revistas de caza en Washington, aunque los actos reflejados hayan tenido lugar en un Estado donde son legales? Y eso mismo cabría decir si pensamos en las artes de caza o pesca, que tampoco son uniformes, o los requisitos para el sacrificio de animales de ganadería. Las peleas de gallos son todavía legales en Puerto Rico, y lo fueron en el Estado de Louisiana hasta el año 2008. Las excepciones establecidas en la norma - el «serio»valor religioso, político, científico, educativo, periodístico, histórico o artístico de lo filmado- exigen ser leídas con enorme amplitud, una amplitud incompatible con tomarse en serio que el valor religioso, político, científico, educativo, periodístico, histórico o artístico sea realmente «serio» como establece el artículo en cuestión. Además, muchas de las películas en las que se muestran imágenes de caza, por ejemplo, difícilmente tienen un valor más allá del recreativo. ¿Por qué sí habrían de ser inherentemente valiosas las exhibiciones de corridas de toros o de caza —como la propia Corte Suprema ejemplifica一, y no así las de peleas de perros en Japón, que es el tipo de material distribuido por el recurrente ${ }^{16}$ ?

15 No deja de resultar paradójico que, en un caso muy semejante, la Corte Suprema consideró que una ordenanza municipal de la ciudad de Hialeah (Florida) en la que se prohibía la crueldad innecesaria con animales y las prácticas sacrificiales era «demasiado específica» (infrainclusiva en relación con el propósito de la evitación de la crueldad hacia los animales), y, por tanto, discriminatoria hacia la religión de la santería (la principal protagonista del uso de animales para rituales y prácticas religiosas); vid. Church of Lukumi Babalú Ayé vs. City of Hialeah, 508 U.S. 520 (1993). Un magnífico comentario a esa sentencia es el de P. CASAL, «Is Multiculturalism Bad for Animals?», Journal of Political Philosophy, vol. 11, núm. 1, 2003: 1-22.

${ }^{16} \mathrm{La}$ sentencia cuenta con un voto disidente del magistrado Alito, que sostiene, en esencia, la improcedente aplicación de la doctrina del «overbreadth» por parte de la Corte Suprema. Dicha doctrina, cuya aplicación debe ser un último recurso según Alito, supone declarar la inconstitucionalidad de una norma de resultas de un cierto juicio de proporcionalidad entre las consecuencias perniciosas derivadas de declarar inconstitucional una norma algunas de cuyas aplicaciones son perfectamente constitucionales, y los inconvenientes de amenazar a los destinatarios con la aplicación de una norma haciendo que dejen de llevar a cabo comportamientos constitucionales. El ejemplo del que se vale la mayoría para sostener esa «suprainclusividad» de la norma que apoyaría su tacha de inconstitucionalidad, la caza, no es adecuado, según Alito, porque la norma claramente prohíbe —o al menos así debe ser interpretada— sólo los comportamientos crueles, con lo que quedarían fuera de su alcance la inmensa mayoría de las películas o representaciones donde se muestran escenas de caza. Incluso si no fuera así, cabría siempre aplicar la excepción de su valor. Lo mismo cabe decir de la «crueldad» que se pudiera mostrar en películas que incluyan escenas sobre sacrificio de animales para el consumo humano u otras prácticas de la ganadería. 
United States vs. Stevens muestra de manera muy vívida el tipo de encrucijada moral y jurídica que propicia nuestra relación con los animales. En España, desde que se promulgara la Constitución española ha crecido un sentimiento a favor de la proscripción de muchas formas de maltrato a los animales y de mejora de sus condiciones vitales y de sacrificio de aquellos animales que son utilizados como recursos para satisfacer necesidades humanas en muy diversos ámbitos. Buena prueba de ello es la proliferación de leyes autonómicas, que, desde la pionera Ley catalana 3/1988, de 4 de marzo, antes mencionada (que ya prohibió la construcción de nuevas plazas de toros en Cataluña), se han dado todas las Comunidades Autónomas ${ }^{17}$. Esa profusión ha discurrido en paralelo al incremento de las leyes estatales que persiguen como objetivos ciertos el de aminorar, cuando no eliminar, el sufrimiento de los animales ${ }^{18}$. El cénit se alcanzó en 2003 con la introducción del delito del maltrato a los animales, una novedad a la que ciertamente coadyuvó un episodio atroz que sucedió en la noche del 3 de noviembre de 2001, cuando unos desconocidos serraron las patas a quince perros que se encontraban en las instalaciones de la Sociedad Protectora de Animales de Tarragona (la mayoría murieron desangrados). En poco más de un mes la Fundación Altarriba recogió cerca de 600.000 firmas instando al Parlamento a que introdujera en el Código Penal los correctivos necesarios para impedir actos de semejante barbarie. Tras la última reforma del Código Penal operada por la Ley Orgánica 5/2010 (BOE de 23 de junio), el art. 337 castiga con la pena de tres meses a un año de prisión e inhabilitación especial de uno a tres años al que: «... por cualquier medio o procedimiento maltrate injustificadamente a un animal doméstico o amansado, causándole la muerte o lesiones que menoscaben gravemente su salud» ${ }^{19}$.

A nivel europeo, la amplia panoplia de directivas y reglamentos sobre bienestar animal ${ }^{20}$ encuentran su cobertura inmediata en el art. 13 del Tratado de Lisboa: «Al formular y aplicar las políticas de la Unión en materia de agricultura, pesca, transporte,

17 Algunas se refieren solo a la protección de los animales domésticos (Canarias, Castilla-La Mancha, Madrid) o de los que viven en el entorno humano (Baleares) o de compañía (Castilla-León, Murcia, Comunidad Valenciana) o de los animales domésticos y de los salvajes en cautividad (Galicia). En el ámbito de sus competencias, estas comunidades también han dictado una profusa normativa sobre otros muchos aspectos relacionados con el trato a los animales en la ganadería, el ocio, etcétera.

${ }^{18}$ Muchas de ellas son, a su vez, trasposiciones de directivas y reglamentos de la Comunidad Europea al ordenamiento jurídico español. Sin pretensión de exhaustividad, vid. la Ley 32/2007, de 7 de noviembre, para el cuidado de los animales, en su explotación, transporte, experimentación y sacrificio; el Real Decreto 348/2000, de 10 de marzo, por el que se incorpora al ordenamiento jurídico la Directiva 98/58/CE relativa a la protección de los animales en explotaciones ganaderas, y las normas relativas al bienestar de los animales de granja: el Real Decreto 692/2010, de 20 de mayo (vacuno y pollos destinados al consumo de carne); el Real Decreto 1221/2009, de 17 de julio (porcino), y el Real Decreto 3/2002, de 11 de enero (gallinas ponedoras).

${ }_{19}$ Fue en el año 2003, mediante la Ley Orgánica 15/2003, cuando se introdujo por primera vez en España el delito de maltrato a los animales aunque se exigía la concurrencia del «ensañamiento» (elemento ahora eliminado tras la reforma de 2010). En esa misma reforma del Código Penal del año 2003 se introdujo la falta del art. 632.2 (que pervive), cuya interpretación — debido a la ambigüedad sintáctica que presenta en su formulación - ha generado una notable controversia. El comportamiento penado es el del maltrato cruel «a los animales domésticos o a cualesquiera otros en espectáculo público no autorizado legalmente». Muchas audiencias provinciales entienden que la circunstancia de haberse dado el maltrato en espectáculo público no autorizado legalmente ha de concurrir en todo caso, con lo que se hace irrelevante la distinción introducida por el legislador entre los animales domésticos y los «cualesquiera otros».

${ }_{20}$ De entre las más recientes, merece la pena destacar el Reglamento 1099/2009, del Consejo, de 24 de septiembre de 2009, relativo a la protección de los animales en el momento de la matanza. 
mercado interior, investigación y desarrollo tecnológico y espacio, la Unión y los Estados miembros tendrán plenamente en cuenta las exigencias en materia de bienestar de los animales como seres sensibles, respetando al mismo tiempo las disposiciones legales o administrativas y las costumbres de los Estados miembros relativas, en particular, a ritos religiosos, tradiciones culturales y patrimonio regional».

Esta disposición, como toda la anterior normativa reseñada, son síntoma de una cierta esquizofrenia ${ }^{21}$ : al anhelo de mejorar el bienestar de los animales que explotamos o conviven con nosotros, y procurar la supervivencia en sus hábitat de los animales salvajes, se suma el afán de seguir permitiendo prácticas y comportamientos de indudable crueldad y maltrato hacia los animales mediante el expediente de la excepción cultural o religiosa. Las corridas de toros son, señaladamente, una de esas prácticas exceptuadas e inmunizadas. El Estado español, dentro y fuera de sus fronteras, no ha dejado de bregar por mantenerlas bajo ese paraguas protector, como exhibió elocuentemente el embajador Javier Elorza, representante de España ante la Unión Europea, en una entrevista publicada en La Vanguardia en 1999: «Nos querían prohibir los toros. Y yo soy taurino hasta el tuétano. Así que - me costó un par de cenas- tramé una estratagema con un gran jurista comunitario: donde decía la UE "velará por el bienestar de los animales...", añadimos "respetando las tradiciones culturales...” ¡Y así blindamos los toros!»22.

La decisión del Parlament de Cataluña de acabar con ese blindaje en Cataluña - a partir de 2012 - mediante la eliminación de la excepción taurina en su propia ley de protección de los animales ha levantado ampollas políticas, éticas, y también jurídico-constitucionales ${ }^{23}$. Tengo para mí que, desde el punto de vista moral, el caso de las corridas de toros es un caso claro: no hay justificación bastante para infligir un sufrimiento atroz — que nadie seriamente pone en duda ${ }^{24}$ - a un animal con las capacidades que tienen los miembros de la especie Bos primigenius taurus. Ni el argumento basado en la tradición, ni el que se apoya en la preservación de la especie, ni el que posterga al bienestar de dichos animales frente a la cultura o el arte o la libertad de empresa o la unidad del mercado, son razones suficientes para la tortura. Pero no me voy a ocupar ahora de este debate ${ }^{25}$, sino de si el actual marco constitucional «prohíbe prohibir» las corridas de toros y a quién se lo prohíbe.

${ }^{21}$ La expresión es de M. NussBaum: «Animal Rights: The Need For A Theoretical Basis», Harvard Law Review, vol. 114, núm. 5, marzo, 1506-1549, 1509-1510.

22 Entrevista de L. Amiguet publicada en la edición de 2 de junio de 1999.

23 Se trata de la Ley 28/2010, de 3 de agosto, de modificación del art. 6 del texto refundido de la Ley de protección de los animales aprobado por Decreto Legislativo 2/2008 (BOE de 24 de agosto de 2010). En el art. 6.1 de dicho texto se establece la prohibición del uso de animales en peleas u otros espectáculos o actividades que les acarree sufrimiento, y se mencionan, no exhaustivamente, cinco actividades prohibidas: las peleas de perros, gallos, las matanzas públicas de animales, atracciones de feria con animales vivos y tiro al pichón. Mediante la Ley 28/2010 se añade una sexta, la letra $f$ ): «Las corridas de toros y los espectáculos con toros que incluyan la muerte del animal y la aplicación de las suertes de la pica, las banderillas y el estoque, así como los espectáculos taurinos de cualquier modalidad que tengan lugar dentro o fuera de las plazas de toros, salvo las fiestas con toros a que se refiere el apartado $2 »$.

${ }^{24}$ M. VARGAS LLOSA — célebre aficionado y defensor de las corridas- ha descrito al espectáculo como «impregnado de violencia y crueldad»; vid. «La última corrida», El País, edición de 2 de mayo de 2004.

25 Me permito remitirme para ello a mi libro Justicia para los animales, Madrid, Alianza, 2003, y a mis alegaciones en el Parlament de Catalunya que fueron publicadas en El cronista del Estado social: «Las corridas de toros: las razones del abolicionismo», núm. 12, abril 2010. 
Y es que no son pocos, ni poco cualificados, quienes entienden que con la abolición se impide el ejercicio de libertades, derechos y bienes constitucionalmente protegidos [como el de desarrollar un oficio o actividad profesional reconocido en el art. 35.1 CE, o el de la creación artística del art. 20.1.b) o la libertad de empresa del art. 38] y se menoscaba la competencia exclusiva del Estado de preservar el «patrimonio cultural común» (arts. 46 y 149.1.28. ${ }^{a} \mathrm{CE}$ ) así como la de garantizar la «unidad de mercado». Ser banderillero, matador o picador son actividades profesionales u oficios, así como expresiones artísticas; las corridas de toros engrosan, indudablemente, el acervo cultural común y son una empresa lucrativa ${ }^{26}$. La inconstitucionalidad de la ley catalana estaría servida. Así lo ha considerado también el Grupo Parlamentario Popular del Senado al interponer un recurso de inconstitucionalidad contra la Ley 28/2010, en octubre de 2010.

Las anteriores apelaciones tienen un respaldo constitucional indudable y poderoso frente a la insignificancia constitucional del bienestar de los animales no humanos, o la proscripción de su sufrimiento gratuito, como he señalado al comienzo. Sin embargo, en lo que sigue trataré de mostrar que los argumentos esgrimidos para sostener la inconstitucionalidad de la abolición de las corridas de toros — los que llamaré «argumento de la protección cultural» y «argumento de la invisibilidad constitucional de los animales no humanos»—- son inconcluyentes.

\section{LAS CORRIDAS DE TOROS Y EL ARGUMENTO DE LA PROTECCIÓN CULTURAL: ¿DE QUÉ CULTURA HABLAMOS?}

El Estado tiene como misión la protección del patrimonio cultural común, como se ha señalado antes. ¿Forman parte las corridas de toros de dicho patrimonio? Para responder afirmativamente - y de manera rotunda- T.-R. FERNÁNDEZ apela a un argumento de autoridad — ciertas afirmaciones de ORTEGA Y GASSET y TIERNO GALVÁN ${ }^{27}$ - y a un argumento «semántico»: el art. 46 de la Ley del Patrimonio Histórico Español (LPHE), de 25 de junio de $1985^{28}$. De todo ello extrae, además,

${ }^{26}$ La argumentación ha sido desarrollada con mayores y menores insistencias y matices por G. DoMÉNECH PASCUAL, «La prohibición de las corridas de toros desde una perspectiva constitucional», cit., y T.-R. FERNÁNDEZ, «Sobre la constitucionalidad de la prohibición de las corridas de toros en Cataluña», en este mismo número.

27 Aunque podrían ser otras muchas las referencias invocadas (así como muchas también las de destacados intelectuales que lucharon denodadamente por la desaparición del festejo, pues lejos de considerarlo una expresión cultural lo tildaban de barbarie), la de ORTEGA (que procede de su obra Una interpretación de la historia universal de 1958) quintaesencia ese tipo de exageración sobre la españolidad y excelencia de las corridas que nutre lo que, en otro lugar, he llamado «ideología taurina»: el conjunto de falsas creencias sobre el origen de las corridas, y el abuso en el empleo del lenguaje metafórico para describir la «cruda realidad» de las mismas; vid. mi Justicia para los animales, op. cit., 281 y ss.

28 «Forman parte del Patrimonio Histórico Español los bienes muebles e inmuebles y los conocimientos y actividades que son o han sido expresión relevante de la cultura tradicional del pueblo español en sus aspectos materiales, sociales o espirituales». Con ello, la LPHE estaría acogiendo bajo el concepto de «patrimonio cultural» los llamados «bienes-actividad» o, como se denominan, por ejemplo, en la Ley del Patrimonio Cultural Vasco, «bienes etnográficos inmateriales»: usos, costumbres, creaciones, comportamientos «... que trascienden de los restos materiales en que puedan manifestarse...» (art. 53 de la Ley 7/1990, de 3 de julio, de Patrimonio Cultural Vasco). Sobre todo ello vid. M. VAQuer CABALlERÍA, Estado y cultura: la función cultural de los poderes públicos en la Constitución española, Madrid, Centro de Estudios Ramón Areces, 1998, 246. 
una conclusión normativa igualmente rotunda que merece la pena transcribir íntegramente:

«En el marco de una Constitución que hace de la libertad y el pluralismo valores superiores del ordenamiento jurídico no cabe reconocer a autoridad alguna competencia para prohibir ni los carnavales, ni el flamenco, la jota o la sardana, ni los encierros de Pamplona, ni la romería del Rocío, ni las procesiones de Semana Santa, ni ninguna otra manifestación cultural. La cultura, como el lenguaje, pertenece al pueblo. Es él exclusivamente quien la crea, la modifica o la transforma. Nadie puede imponérsela contra su voluntad, nadie puede quitársela tampoco. La cultura está en este sentido más allá de la Ley, fuera del alcance de la Ley» ${ }^{29}$.

Hay, como se sabe, una definición «neutral», descriptiva, de «cultura», como el entramado de «modos de hacer las cosas»; de todas aquellas formas de adaptación al medio que no son heredadas genéticamente, sino transmitidas mediante el aprendizaje. En la definición clásica de E. B. TYLOR (1871) cultura es: «... aquel todo complejo que incluye el conocimiento, las creencias, el arte, la moral, el Derecho, las costumbres y cualesquiera otros hábitos y capacidades adquiridos por el hombre en cuanto miembro de la sociedad» ${ }^{30}$. El propio preámbulo de la LPHE se refiere a la cultura «material» como «acción del hombre en sentido amplio». Es desde esta perspectiva desde la que cabe señalar que no hay personas «incultas», salvo que nos refiramos a individuos absolutamente inhábiles para desarrollarse en su medio (social y natural), de la misma manera que hablamos de analfabetos o ineducados. El Estado protege la cultura en este sentido, y garantiza el derecho a su acceso, de forma muy semejante a como procura la educación a todos los ciudadanos: aportándoles los instrumentos y herramientas cognitivas e intelectuales que les permitan desarrollar su autonomía personal en el entorno social que les ha tocado vivir, en esa, su «cultura».

En un sentido «normativo», cultura sólo incluiría el acervo de conocimientos «valiosos o excelsos» ${ }^{31}$. De nuevo, en el preámbulo de la LPHE, junto con la «cultura» en sentido neutral se hace referencia al «... conjunto de bienes que en sí mismos han de ser apreciados... (a la) riqueza colectiva que contiene las expresiones más dignas de aprecio en la aportación histórica de los españoles a la cultura universal. Su valor lo proporciona la estima que, como elemento de identidad cultural, merece a la sensibilidad de los

29 «Sobre la constitucionalidad de la prohibición de las corridas de toros en Cataluña», en este mismo número (cursivas mías).

${ }^{30}$ He tomado la cita de J. Prieto De Pedro, Cultura, culturas y constitución, Madrid, Congreso de los Diputados-Centro de Estudios Constitucionales, 1993: 24-25. Más recientemente, lo cultural como «... imposición de lo arbitrario sobre el medio» constituye la célebre definición del antropólogo R. L. HOLLOWAY Jr., para, de esa forma, hacer a los seres humanos los únicos animales «culturales»; vid. «Culture: A Human Domain», Current Anthropology, vol. 10, núm. 4, octubre 1969: 395-412, 395, 397, 399-400. La forma de organización de la experiencia y su transmisión «arbitraria», esto es, mediante instrumentos (paradigmáticamente el lenguaje) que no son representaciones «icónicas» de lo referido (que no tratan de guardar similitud ninguna con el objeto, acción o escenario de referencia) es lo característicamente «cultural». Es por ello por lo que, de acuerdo con esta corriente, no tiene sentido hablar de «cultura de los chimpancés», aunque haya sido demostrado que ciertas poblaciones de chimpancés, pero no otras, manipulan su entorno para su beneficio - mediante formas muy primarias de preparar alimentos, por ejemplo, o de construir herramientas de las que valerse- Vid., respectivamente, los clásicos trabajos de S. KAWAMURA, «The process of subcultural propagation among Japanese macaques», Primates, núm. 2, 1959, 43-60, y J. Mosterín, Filosofía de la cultura, Madrid, Alianza Universidad, $1993,50-54$.

31 Sobre los orígenes históricos de esta acepción, vid. J. Mosterín, Filosofía de la cultura, op. cit., 16-17. 
ciudadanos» (cursivas mías) ${ }^{32}$. La persona culta se distinguiría por conocer y apreciar las expresiones (supuestamente) más refinadas de ese entramado, aquellas manifestaciones artísticas o científicas más singulares por el especial esfuerzo que tuvo que ser empleado para su creación, o la capacidad cognitiva, o destreza manual, o técnica o imaginación que denotan ${ }^{33}$.

En último término nos referimos con «cultura» a las actitudes, creencias, y valores compartidos que serían característicos de una institución, organización o grupo (así, se habla de la «cultura» de empresas determinadas, como su singular modo de producir o desarrollar el negocio frente a sus competidoras) ${ }^{34}$.

Despejado mínimamente el campo conceptual, chasta qué punto es cierta la contundente, y sorprendente, afirmación de T.-R. FERNÁNDEZ de que la cultura - y por ende las corridas de toros- están «... más allá de la ley, fuera del alcance de la ley»?

En primer lugar, tomando «cultura» en el que he denominado sentido «neutral» o «descriptivo», es verdad que resulta muy difícil, fácticamente, y de muy dudosa corrección moral, por lo que de ataque a la libertad individual y colectiva supone, que el poder público impida ciertas expresiones culturales o imponga otras, cercenando así la espontaneidad del modo en el que los individuos nos acabamos relacionando con el medio y entre sí. Pero repárese en que una tal intervención del poder público no resulta fácticamente imposible: el propio T.-R. FERNÁNDEZ censura al empeño hodierno de favorecer el catalán en Cataluña frente al castellano, y, cabría aludir en esa misma línea, al afán franquista de antaño de impedir el uso del catalán en Cataluña, o la prohibición de los carnavales, ejemplo que también figura en el elenco que nos proporciona FERNÁNDEZ de manifestaciones culturales «más allá de la ley». Sí resultarían absurdas las injerencias extremas: el intento de imponer, por parte del poder público, culturas o lenguas completamente ajenas, como muestra la célebre e hilarante escena de Bananas de Woody Allen ${ }^{35}$.

Ahora bien, en esta primera dimensión de lo cultural hay manifestaciones o expresiones culturales que una Constitución que hace del pluralismo y la libertad sus valores superiores, pero que también incorpora la garantía de ciertos derechos básicos, no sólo puede legítimamente prohibir, sino que debe hacerlo. Durante siglos, los seres humanos han impuesto sanciones de maneras muy diversas en aras al mantenimiento de la

32 A este sentido axiológico es al que, aparentemente, se estaría aludiendo en la Constitución española con el término «cultura»; vid. A. PAU y M. J. RoCA, «Arte y poder», en Estado y cultura, Madrid, Fundación Coloquio Jurídico Europeo, 2009: 49-142, 55, y M. VAquer, Estado y cultura, op. cit., 92-94, 98. Por otro lado, es ese sentido normativo del término, y la correspondiente obligación del Estado de fomentar o proteger lo juzgado como excelente o apreciable culturalmente, lo que pone en peligro la necesaria neutralidad del Estado y lo que ha llevado al Tribunal Constitucional alemán a considerar que ese control de contenidos del arte por parte del Estado - que se erige así en una suerte de juez estético— resulta constitucionalmente inadmisible; vid. S. Huster, «La cultura en el Estado constitucional», en Estado y cultura, Madrid, Fundación Coloquio Jurídico Europeo, 2009, 13-47, 18-19.

33 Esta forma de «alta cultura» se contrapone a la llamada «cultura popular», la que aprecia y disfruta el individuo corriente que ve en ella sobre todo una fuente de entretenimiento, lo cual permite incluir al deporte o a la moda también como parte de la cultura.

34 Un catálogo de otras posibles acepciones lo aporta J. PRIETO DE PEDRO, Cultura, culturas y constitución, op. cit., 26.

${ }^{35}$ Nada más proclamarse presidente de San Marcos, una isla caribeña, el dictador —indisimuladamente semejante a Fidel Castro- declara que a partir de ese momento la lengua oficial en el país será el sueco. 
paz y de la convivencia en sus comunidades. Durante siglos, todos esos grupos - tribus, naciones, Estados - han aplicado la pena de muerte como castigo máximo y la tortura como método para la persecución del crimen o como sistema de control social. No todos esos colectivos lo han hecho de la misma manera, y el ingenio o sutileza, atrocidad o bondad en la que se ha provocado deliberada e institucionalmente la muerte a otro individuo, o su sufrimiento para domeñar su voluntad resistente, conforman la «cultura de la pena de muerte» o la «cultura de la tortura». La guillotina es parte de la cultura francesa como el foie-gras; el potro y el garrote vil de la cultura española tanto como las corridas de toros y el flamenco. La inmensa mayoría de la ciudadanía en España, con buenas razones, no estuvo dispuesta en el momento constituyente a preservar, y mucho menos fomentar, esa parte de «... los conocimientos y actividades que son o han sido expresión relevante de la cultura tradicional del pueblo español en sus aspectos materiales, sociales o espirituales» (prólogo de la LPHE) ${ }^{36}$. No es extraño, por ello, que en uno de los principios rectores de la Convención sobre la protección y la promoción de la diversidad de las expresiones culturales de la UNESCO se lea que: «Nadie podrá invocar las disposiciones de la presente Convención para atentar contra los derechos humanos y las libertades fundamentales proclamados en la Declaración Universal de Derechos Humanos y garantizados por el Derecho internacional, o para limitar su ámbito de aplicación» (art. 2.1) ${ }^{37}$.

¿Forman parte las corridas de toros de la «cultura» entendida «normativamente»? ¿Son una de esas manifestaciones «dignas de aprecio» de nuestra condición humana, característica de nuestras capacidades artísticas e intelectuales, de nuestro ingenio? Aquí la discusión se torna más intratable por subjetiva ${ }^{38}$. Tomemos, por ejemplo, a uno de los pensadores contemporáneos que en España más ha defendido el valor del espectáculo taurino: V. GÓMEZ PIN. A su juicio, la tauromaquia es una «exigencia ética» pues las corridas de toros constituyen una ocasión sin par para representar y reivindicar nuestra humanidad ${ }^{39}$. Lo hacemos en el espectáculo taurino sacrificando

36 La Corte Constitucional de Colombia tuvo ocasión de expresar esta misma idea al enjuiciar la constitucionalidad del Reglamento de Espectáculos Taurinos en la sentencia C-1192/05 ya mencionada (vid. supra nota 8). En sus propias palabras: «Así las cosas, no todas las actividades del quehacer humano que expresan una visión personal del mundo, que interpretan la realidad o la modifican a través de la imaginación, independientemente de que en su ejecución se acudan al auxilio de recursos plásticos, lingüísticos, corporales o sonoros, pueden considerarse por parte del legislador como expresiones artísticas y culturales del Estado. En efecto, es preciso recordar que conforme al preámbulo y a los arts. 1, 2, 4 y 13 de la Constitución Política, esta Corporación ha reconocido que el criterio jurídico de razonabilidad — en tanto límite a la potestad de configuración normativas - implica la exclusión de toda decisión que éste adopte y que resulte manifiestamente absurda, injustificada o insensata, vale decir, que se aparte por completo de los designios de la recta razón, lo que ocurriría, por ejemplo, al pretenderse categorizar como expresiones artísticas y culturales del Estado, comportamientos humanos que única y exclusivamente manifiesten actos de violencia o de perversión $(v$. gr. la pornografía, el voyerismo y el sadismo), que además de considerarse lesivos de los valores fundamentales de la sociedad, desconocen principios y derechos fundamentales como los de la dignidad humana (CP arts. 1 y 12) y la prohibición de tratos crueles (CP art. 12)».

37 La Convención fue hecha en París el 20 de octubre de 2005. España la ratificó el 18 de diciembre de 2006. Es precisamente de la UNESCO de donde procede la noción de «bien cultural» y del Derecho internacional la de «patrimonio cultural»; vid. VAQUER, Estado y cultura, op. cit., 239-240, 253-254.

38 Para una mayor profundización en el tema, en las páginas de este mismo número se puede consultar el enriquecedor trabajo de F. LARA, «Animales y espectáculos».

39 También F. WolfF ha reivindicado el «imperativo ético» de las corridas de toros. Sus razones, sin embargo, son distintas a las de GÓMEZ PIN: a su juicio lidiar en el coso al toro y sacrificarle según los cánones de la corrida es el mejor tributo que podemos rendir a su condición de animal «bravo» que estaría, por decirlo 
al animal que también somos, despidiéndonos de esa, nuestra condición, que debe ser superada haciéndonos conscientes de la condición de mortales que nos acompaña ${ }^{40}$. ¿No basta para tales reivindicaciones con las representaciones, con la teatralización o la filmación de hechos ficticios, que no supone, en ninguno de los casos, la inflicción de sufrimiento real a un ser sintiente?

Si lo que tiene de valioso la expresión artística radica en la destreza singular del ejecutante o creador, ciertamente quienes participan en la lidia son artistas (unos mejores y otros peores) en su despliegue corporal al enfrentarse al animal. Y el espectáculo es culturalmente apreciable en su conjunto por la concurrencia de otros elementos que son valiosos por la historia que les acompaña o por el esfuerzo que se emplea en su producción (los trajes, por ejemplo). Todo ello contribuye a dotar a las corridas de toros de la consideración de «bien cultural». Puede que así sea, aunque incluso para el apologeta de las corridas antes mencionado, GómEZ PIN, la tauromaquia no es un arte ${ }^{41}$.

En todo caso, la pregunta que a nosotros, juristas y filósofos del Derecho, interesa es si pueden seguir conservándose desde el momento en que es abrumadora la evidencia de que generan un enorme sufrimiento a parte de los (involuntarios) protagonistas. Mi respuesta es que no, que incluso si conforman el patrimonio cultural español, su fomento, defensa o conservación debería encontrar un límite como el señalado. ¿Pero es ese - el de evitar el sufrimiento del animal - un límite constitucionalmente amparado? Por razones de legitimidad democrática, sobre las que abundaré posteriormente, me parece a mí que la cuestión es más bien la de si imponer ese límite está constitucionalmente probibido. Por dichas razones vinculadas al ideal democrático, defenderé que no hay tal prohibición constitucional a impedir la celebración de corridas de toros incluso si son considerables como un bien cultural o como parte integrante del patrimonio cultural común. Tal y como afirma el Tribunal Supremo en la STS de 20 de octubre de 1998, «... no es razonable entender que el deber que a los poderes públicos incumbe de garantizar la conservación y promover el enriquecimiento del patrimonio cultural (art. 46 de la Constitución), impone la obligación de interpretar las leyes de modo incondicional en sentido favorable al mantenimiento de todas las manifestaciones in-

así, reclamándonos ese final. Esta extravagante argumentación pende de premisas etológicas y zoológicas que la comunidad científica considera puras invenciones. Por otro lado, genera la paradójica e increíble consecuencia de que tengamos que censurar a todos aquellos países que sacrifican a los toros de manera indolora y sin que medien corridas de toros — con todas las suertes acostumbradas - de por medio. Vid. Filosofía de las corridas de toros, Barcelona, Ediciones Bellaterra, 2010 (1. ${ }^{a}$ ed., 2007).

40 La escuela más sobria de la vida. Tauromaquia como exigencia ética, Madrid, Espasa Calpe, 2002: 42-43, $58-59,97,149,218$ y 223.

${ }_{41}$ Aunque las razones que esgrime para sostenerlo son, lo confieso, incomprensibles para mí «[1]a tauromaquia — señala— no es clasificable como arte por la sencilla razón de que este vocablo designa... un conjunto de tareas humanas cuya realización y proyección social es perfectamente compatible con la persistencia en sus receptores de una abulia espiritual que la tauromaquia (por su intrínseca radicalidad) apunta a abolir. La tauromaquia no es, de entrada, clasificable como arte porque éste, en sus modalidades convencionales, es excesivamente respetuoso con los parapetos que la cultura ha fraguado para evitar que se restaure la exigencia de verdad, la exigencia de desvelamiento, exigencia indisociable de una radical confrontación que es, de hecho, el motor originario de la obra de arte y lo único que le otorga legitimidad... La tauromaquia no es clasificable como arte porque, en la forma misma, este muy a menudo se complace en las brumas que impiden la percepción nítida de la dificultad a vencer, mientras que la primera condición de la tauromaquia es la delimitación (no ya rigurosa, sino exacta) de la dificultad y, en consecuencia, la vigencia en todo momento del juicio claro del torero»; La escuela más sobria de la vida, 134. 
herentes a los espectáculos tradicionales sin tener en cuenta otros intereses y derechos protegidos y, en lo que aquí especialmente interesa, otros valores culturales, a veces contrapuestos, que deben ser adecuadamente ponderados» ${ }^{42}$.

\section{CULTURAS, ESPECTÁCULOS Y UNIDAD DE MERCADO: EL ARGUMENTO COMPETENCIAL}

Un segundo aspecto de la controversia en torno a la constitucionalidad de la ley que abole las corridas de toros en Cataluña es la de determinar si esa es o no una competencia que las Comunidades Autónomas puedan ejercer. Para T.-R. FERNÁNDEZ, entre otros, de los preceptos que se invocan del Estatuto de Cataluña (EAC) para sustentar la prohibición que supone la Ley 28/2010 (los arts. 46, 116, 141, 144 y 189) ${ }^{43}$ sólo son prima facie atendibles los arts. 116.1.d) y 141. El primero establece que: «Corresponde a la Generalitat, respetando lo establecido por el Estado en el ejercicio de las competencias que le atribuye el art. 149.1.13 y 16 de la Constitución, la competencia exclusiva en materia de agricultura y ganadería. Esta competencia incluye en todo caso... La sanidad vegetal y animal cuando no tenga efectos sobre la salud humana y la protección de los animales». El segundo atribuye a la Generalitat la «... competencia exclusiva en materia de espectáculos y actividades recreativas, que incluye, en todo caso, la ordenación del sector, el régimen de intervención administrativa y el control de todo tipo de espectáculos en espacios y locales públicos». El primer título encontraría el límite del respeto a las bases de la ordenación general de la actividad económica que, de acuerdo con el art. 149.1.13 de la Constitución, corresponde fijar al Estado. La prohibición de las corridas de toros supone, en definitiva, poner palos en las ruedas del desarrollo de un sector importante de la economía española en Cataluña, es decir, rompería unilateralmente la «unidad de mercado» por impedir la libre circulación de bienes y personas en todo el territorio nacional, y la igualdad de condiciones básicas en el ejercicio de la actividad económica vinculada al festejo taurino.

No hay duda de que la política económica, entendida como la fijación de los grandes objetivos macroeconómicos y las políticas monetarias, fiscales y de comercio exterior adecuadas para lograrlos, recae en manos del Estado, de acuerdo con el art. 149.1.13 CE, aunque no se deben olvidar los muy estrechos márgenes que, para el desarrollo de dichas políticas, tienen hoy los Estados integrados en la UE. La STC 29/1986, de 20 de febrero (relativa a los Decretos de reconversión y reindustrialización) atribuye al Estado la potestad de asegurar la «unidad de la política económica» incluso mediante la ordenación de aquellos sectores económicos asumidos en exclusiva por las CC.AA. en sus Estatutos. Puesta en manos del Estado, se trata de una interpretación del precepto constitucional que el propio Tribunal Constitucional ha tenido que atemperar pues pudiera conducir al vaciamiento de las competencias auto-

42 RJ 1998/8923. El caso se originó cuando la Generalitat de Catalunya sancionó al Ayuntamiento de Cardona por haberse dado muerte a cuatro toros durante la celebración de un corre bous, hecho éste con el que se infringía la Ley 3/1998 de Cataluña de protección de los animales.

${ }_{43} \mathrm{El}$ art. 46 establece que la obligación de los poderes públicos de proteger el medio ambiente; el 144 establece la competencia compartida sobre medio ambiente, espacios naturales y meteorología y el art. 189 se refiere al desarrollo y ejecución del Derecho de la Unión Europea. 
nómicas. De esa forma, se exige entre otros requisitos, que la medida impuesta por el Estado, al amparo del art. 149.1.13 CE, tenga una incidencia «directa y significativa» en la actividad económica general. Además, el TC ha exigido que esas medidas del Estado adoptadas bajo el paraguas de la ordenación general de la actividad económica se limiten a lo «básico» ${ }^{44}$.

En relación con la «regulación de las condiciones básicas que garanticen la igualdad de todos los españoles» que se vería vulnerada por la Ley 28/2010 al limitar el ejercicio de las actividades profesionales y empresariales vinculadas el festejo taurino, el TC ha insistido, lógicamente, en que ello ha de hacerse compatible con la descentralización, con lo que no cabe imponer «una rigurosa y monolítica uniformidad del ordenamiento jurídico» que pudiera erigirse en un escollo infranqueable para la potestad normativa de las CC.AA. (SSTC 37/1981, de 16 de noviembre; 102/1985, de 4 de octubre, y 37/1987, de 26 de marzo) ${ }^{45}$. En la STC 52/1988, de 24 de marzo, el Tribunal Constitucional, al juzgar la constitucionalidad de la Ley 15/1984 del Parlamento de Cataluña del juego y la presunta vulneración en la misma de las garantías, principios y preceptos constitucionales que sostienen la unidad de mercado, señala: «Es evidente que dicha regulación autonómica puede afectar a las industrias dedicadas a la fabricación de tales materiales o instrumentos, pero ello sólo determinaría la atribución al Estado de la competencia para regular las características de los mismos si esta regulación hubiera de entenderse comprendida entre los aspectos básicos de la actividad económica general —art. 12.1 del Estatuto de Autonomía de Cataluña- o entre las condiciones básicas que permiten garantizar la igualdad de los españoles en el ejercicio de los derechos y en el cumplimiento de los deberes constitucionales — art. 149.1.1 de la CE—y, en concreto, en el ejercicio de la libertad de empresa» (FJ 4).

De todo ello se infiere el que, a mi juicio, la Generalitat de Catalunya puede perfectamente afectar a un sector económico no básico de la actividad económica del conjunto del Estado - y mucho menos básico, obviamente, si el marco de referencia es la Unión Europea-, pues, como veremos a continuación, cuenta con las competencias necesarias tanto para la regulación de los espectáculos públicos cuanto para la protección de los animales en ellos involucrados.

T.-R. FERNÁNDEZ estima, sin embargo, que la competencia de las Comunidades Autónomas en materia de espectáculos lo sería a los solos efectos del ejercicio de la policía administrativa, esto es, el conjunto de «facultades y poderes dirigidos a asegurar un desarrollo ordenado de los mismos» ${ }^{46}$. A dicha interpretación coadyuvaría la lectura del Decreto de traspaso de competencias (RD 1771/1985, de 1 de agosto), donde el Estado se reserva la competencia para la suspensión o prohibición de espectáculos, así como algunas sentencias del Tribunal Constitucional (SSTC 49/1984 y 153/1985) que abundarían en esa dirección.

44 A. CIDONCHA, «La unidad de mercado como límite constitucional a la descentralización: un balance», en La unidad de mercado en la España actual, VV.AA., Madrid, Instituto de Estudios Económicos, 2010, 155192,162 y ss.

${ }^{45}$ He tomado las referencias de estas sentencias de H. Villarejo y A. Calonge, «Unidad de mercado y comercio interior», en La unidad de mercado en la España actual, op. cit., 193-249, 209, n. 14.

46 T.-R. FERNÁNDEZ, «Sobre la constitucionalidad...», en este volumen. 
Antes de afrontar directamente este argumento, interesa hacer algunas consideraciones preliminares relativas a lo que ha venido ocurriendo en relación con las manifestaciones culturales en España en las que se hace uso de animales, y las muchas constricciones o reformas, cuando no directas supresiones, a las que han procedido distintas Comunidades Autónomas. Ese recorrido resulta pertinente a los efectos de juzgar el presunto «exceso competencial» en el que habría incurrido el Parlament de Catalunya, y para reivindicar, también, una lectura de la distribución en materia cultural que es mucho más atenta a la realidad de diversidad plurinacional del Estado español que la visión uniformadora y homogeneizadora que destila el planteamiento de T.-R. FERNÁNDEZ ${ }^{47}$.

Muchas culturas, y, concretamente, diversas expresiones culturales muy españolas (y muy crueles con los animales), han venido siendo reformadas en los últimos años, e incluso prohibidas, por parte de autoridades varias que han sido sensibles a las demandas de quienes consideran que el maltrato a los animales no está justificado ni por la diversión, ni por la tradición. En Lekeitio, hasta 1986 se celebraba una fiesta popular («El día de los gansos» o «Antzar Eguna») en la que los mozos nadaban hasta una cuerda donde pendían gansos vivos a los que aquellos trataban de descabezar. Hoy se sigue celebrando, aunque el ganso es previamente sacrificado. El grupo Berdeak-Los Verdes reclama que se utilicen gansos de plástico.

Las corridas de toros son también una de las muchas manifestaciones del uso y abuso de animales para nuestro esparcimiento, ocio o expresión «artística». El espectáculo o la fiesta taurina no es un producto únicamente español aunque en ningún otro país como en el nuestro han arraigado y perdurado durante tanto tiempo. En la Inglaterra del siglo XVII los festejos con toros y perros (bull baiting) fueron sumamente populares, así como en otros lugares de Europa, como resulta bien sabido.

No se puede negar, por tanto, que en la cultura española el festejo con animales «estrella» ha sido el taurino, pero tampoco cabe discutir que ese espectáculo ha ido variando de manera muy importante a lo largo de siglos: la actual corrida de toros (tradición que, según los expertos, no aparece hasta el siglo XVIII) arranca, por lo que parece, con el alanceamiento del toro a caballo, una diversión protagonizada entonces por la nobleza, y que hoy se mantiene como «espectáculo» en Tordesillas (Valladolid) ${ }^{48}$. De hecho, como es también conocido, en distintos momentos de nuestra historia la autoridad pública ha eliminado algunos de los elementos más característicos de las corridas de toros, elementos que entonces eran también «tradicionales» —el parapeto de los caballos de la suerte de varas- llegando hasta su total prohibición a principios del siglo XIX ${ }^{49}$.

$47 \mathrm{Vid}$, en esa línea, VAQUER, quien encuentra consagrado constitucionalmente el pluralismo cultural en el preámbulo de la Constitución, o en la atribución de valor cultural a las modalidades lingüísticas de España (art. 3.3) o en la imputación del patrimonio cultural a diversos pueblos de España. El pluralismo cultural sería, al cabo, el fundamento mismo de la descentralización que acompaña a la Constitución; vid. Estado y cultura, op. cit., 175.

${ }^{48}$ Desde hace años, el día de su celebración a principios de septiembre se provocan manifestaciones de repulsa y muy serios. Se trata de una expresión cultural que se celebra bajo la intermediación severa de la Guardia Civil.

49 Así, mediante la Pragmática sanción de 14 de noviembre de 1785 Carlos III impone prohibiciones condicionadas a la fiesta, y, en 1805, su hijo Carlos IV los prohíbe absolutamente. En 1908, mediante Real 
La autoridad pública sigue procediendo a esas restricciones incluso tras el levantamiento de la prohibición de las corridas de toros que supuso la aprobación en 1991 de la Ley 10/1991, de 4 de abril, sobre potestades administrativas en materia de espectáculos taurinos. El Estado, pero también algunas Comunidades Autónomas, han establecido limitaciones y prohibiciones en su desarrollo, que llegan hasta la posibilidad misma de su existencia; han promulgado normas que pueden ser vistas como formas de «modular» o «reconstruir» la tradición cultural bajo nuevos parámetros como el de conjugar la evitación del sufrimiento de los animales. Y todo ello al amparo de la propia Ley 10/1991 en cuya disposición adicional 1. a se puede leer: «Lo establecido en la presente Ley será de aplicación general en defecto de las disposiciones específicas que puedan dictar las Comunidades Autónomas con competencia normativa en la materia, correspondiendo su ejecución a los órganos competentes de aquéllas, sin perjuicio de las facultades atribuidas al Estado en relación con los espectáculos taurinos».

Así, la Comunidad Autónoma de Madrid en el Reglamento de Espectáculos Taurinos Populares (Decreto de la Consejería de Presidencia, núm 112, de 25 de julio de 1996), después de definir y reglamentar los encierros y las sueltas de reses, prohíbe en su art. 3.2 los espectáculos taurinos que impliquen maltrato a las reses, y, concretamente: «Los espectáculos consistentes en embolar a las reses, prendiendo fuego al material o sustancia con que se ha realizado el embolado o en sujetar antorchas a sus astas. Los espectáculos consistentes en atar a las reses con maromas, sogas o de cualquier otra manera». Es decir, en la Comunidad Autónoma de Madrid se prohibieron en 1996 dos típicas manifestaciones culturales de otras zonas de España, entre ellas, Cataluña: el que allí denominan «bou embolat» y «bou capllaçat».

Lo mismo podemos decir del Decreto 87/1998, de 28 de julio, que aprueba el Reglamento de Espectáculos Taurinos Populares de Castilla-La Mancha (DOCM de 28 de agosto) en cuyo art. 3.2 se prohíben aquellos espectáculos taurinos que impliquen maltrato a las reses y, especialmente: «Los espectáculos consistentes en embolar a las reses, prendiendo fuego al material o sustancia con que se ha realizado el embolado, o en sujetar antorchas o elementos similares a sus cuernos», y «Los espectáculos consistentes en atar a las reses, a un punto fijo, con maromas, sogas, o de cualquier otra forma». En Castilla-La Mancha, por tanto, no está permitido el espectáculo taurino que el Decreto 30/1996 de 31 de mayo que aprueba el Reglamento de Espectáculos Taurinos Tradicionales de la Comunidad Autónoma de La Rioja (BOLR de 4 de junio) permite expresamente por tener el carácter de festejo taurino tradicional (art. 3): el «toro ensogado en Cenicero y Cabretón» (B. ${ }^{\circ}$ de Cervera del Río Alhama).

Y la expresión máxima de dicha actuación moduladora o incluso prohibitiva por parte de la autoridad es la Ley 8/1991, de 30 de abril, de protección de los animales de la Comunidad Canaria. En dicha norma, se prohíben, sin excepciones, los maltratos a los animales, «... someterlos a cualquier práctica que les pueda producir sufrimientos o daños injustificados» (art. 2). Además: «Se prohíbe la utilización de animales en peleas, fiestas, espectáculos y otras actividades que conlleven maltrato, crueldad o su-

Orden, Juan de la Cierva prohíbe la suelta de reses por calles y plazas de los pueblos, lo cual generó revueltas y tumultos populares. Sobre todo ello, vid. T.-R. FERnÁNDEZ, «Los toros bravos», en S. Muñoz Machado (ed.), Los animales y el derecho, Madrid, Civitas, 1999, 119-133, 130-131. 
frimiento» (art. 5). Ambos preceptos permiten sostener que las corridas de toros están prohibidas en Canarias $^{50}$.

Las corridas de toros han venido manteniendo su posibilidad como excepción propia en las leyes de protección de los animales que, como antes señalaba, han proliferado desde la pionera norma catalana en todas las Comunidades Autónomas. Han sido, por tanto, una excepción a la regla general prohibitiva de no maltratar cruelmente a los animales que están bajo nuestro dominio ${ }^{51}$. Canarias sólo mantuvo la excepción permisiva expresa — aun con restricciones— de su festejo popular idiosincrásico —y también cruel - con los animales: las peleas de gallos. Y es lamentable que lo haya hecho, como es lamentable ahora que en Cataluña no se haya aprovechado también para eliminar la excepción de los corre-bous. En todo caso: ¿no hay algo extraño en defender, mantener y fomentar el patrimonio cultural con el que se categoriza a las corridas de toros, bajo el manto de lo «excepcional»? Sea como fuere, ni entonces — cuando normativamente Canarias dejó de blindar excepcionalmente las corridas de toros - ni antes — cuando dejaron de celebrarse por la colectiva pérdida de interésel Estado sintió llamada alguna a defender y fomentar el «patrimonio cultural común» que supuestamente engrosan las corridas de toros, ni tampoco instó a la declaración de inconstitucionalidad de la ley canaria, cosa que indudablemente hubiera debido hacer si, pongamos, la Comunidad Canaria hubiera decidido permitir mediante ley la venta de inmuebles como la torre de El Tostón en Fuerteventura ${ }^{52}$.

Todo lo anterior abona la posibilidad de que la Comunidad Autónoma de Cataluña, en el ejercicio de sus competencias sobre cultura y espectáculos, decida prohibir de manera radical las corridas de toros en atención a la protección de los animales, competencia expresamente asumida en el Estatuto aprobado por Ley Orgánica 6/2006, de 19 de julio, de reforma del Estatuto de Autonomía de Cataluña, asunción sobre la que el Tribunal Constitucional no ha encontrado tacha de inconstitucionalidad alguna en su STC 31/2010, de 28 de junio. Como afirma DoméNECH PASCUAL: «... tampoco sería descabellado sostener que el art. 141.3 del Estatuto de Autonomía de Cataluña, interpretado a la vista de la realidad social actual, permite al legislador catalán regular los espectáculos en atención a otros fines públicos distintos de los tradicionales (se refiere a la moralidad pública, la integridad física de los participantes, la tranquilidad de los afectados y la comodidad de los espectadores) pero considerados legítimos y cuya gestión no ha sido inequívocamente encomendada al Estado por la Constitución. De hecho (como he

50 Dice T.-R. FERNÁNDEZ al respecto, que la ley canaria mantuvo la excepción expresa de las peleas de gallos, lo cual es cierto, y que, en relación con las corridas de toros «guardó silencio» (vid. su contribución en este número). Ciertamente lo hizo, como en relación a las peleas entre osos y perros (que divirtieron enormemente al pueblo madrileño en su día), o el lanzamiento de una cabra desde un campanario (que hasta hace muy poco se celebraba en la zamorana localidad de Manganeses de la Polvorosa al inicio de las fiestas de San Vicente), por poner solo dos entre los infinitos ejemplos de «silencio» posibles. Por simple subsunción en el resto del art. 5 de la ley canaria, las corridas de toros están prohibidas en esa Comunidad.

51 Como destaca oportunamente DOMÉNECH PASCUAL esa técnica legislativa no puede evitar «las connotaciones negativas inevitablemente asociadas a toda regulación excepcional»; «La prohibición de las corridas de toros desde una perspectiva constitucional...», op. cit., 18.

52 Esta es también la tesis sostenida por la magistrada Núria Clèries en su voto discrepante en la Sentencia del Tribunal Superior de Justicia de Cataluña 854/2001, de 11 de julio. De acuerdo con la argumentación de la mayoría, que estima que la prohibición del rejoneo de un toro que se iba a practicar como parte de la representación de una ópera contraría la libertad artística, la ley de protección de los animales catalana es presuntamente inconstitucional y por tanto debieran haber elevado la correspondiente cuestión de inconstitucionalidad. 
tenido oportunidad de pormenorizar anteriormente) prácticamente todos los legisladores autonómicos han interpretado en este sentido los preceptos equivalentes de sus respectivos Estatutos, al prohibir por regla general los espectáculos en que se maltrate a los animales, sin que las autoridades estatales hayan discutido nunca estas probibiciones» ${ }^{53}$.

Como en tantos otros ámbitos, la distribución competencial sobre cultura y espectáculos entre el Estado y las Comunidades Autónomas no ha sido pacífica. No sólo Cataluña, sino también Galicia y el País Vasco, sostuvieron muy tempranamente frente a la Ley 16/1985, de 25 de junio, reguladora del Patrimonio Histórico, que la competencia exclusiva del Estado sobre la «defensa del patrimonio cultural común» (art. 149.1.28. ${ }^{a}$ de la $\mathrm{CE}$ ) en el que supuestamente quedarían engrosadas las corridas de toros según la tesis de FERNÁNDEZ, lo era a los solos efectos de evitar la expoliación y la expropiación, tal y como literalmente reza el 149.1.28. ${ }^{a}$ CE. El TC en su STC 17/1991, de 31 de enero, negó que la competencia estatal se limitara a esos supuestos, pues se trata de bienes «dotados de singulares características... patrimonio cultural de todos los españoles e incluso de la Comunidad internacional por constituir una aportación histórica a la cultura universal» (FJ 2), insistiendo en el carácter concurrente de la competencia, y añadiendo que: «No cabe sin embargo extender la competencia estatal a ámbitos no queridos por el constituyente, por efecto de aquella incardinación general del patrimonio histórico-artístico en el término cultural... El Estado ostenta, pues, la competencia exclusiva en la defensa de dicho patrimonio contra la exportación y la expoliación, y las Comunidades Autónomas recurrentes en lo restante según sus respectivos Estatutos; sin que ello implique que la eventual afectación de intereses generales o la concurrencia de otros títulos competenciales del Estado en materia determinada no deban también tenerse presentes como límites que habrá que ponderar en cada caso concreto» (FJ 3).

Si de fenómeno cultural hablamos, el Tribunal Constitucional, al interpretar el art. 44.1 de la CE en la Sentencia 49/1984 a la que se refiere FERNÁNDEZ, ha tenido ocasión de señalar que: «... una reflexión sobre la vida cultural, lleva a la conclusión de que la cultura es algo de la competencia propia e institucional tanto del Estado como de las Comunidades Autónomas, y aun podríamos añadir de otras Comunidades, pues allí donde vive una comunidad hay una manifestación cultural respecto de la cual las estructuras públicas representativas pueden ostentar competencias, dentro de lo que entendido en un sentido no necesariamente técnico-administrativo puede comprenderse dentro de "fomento de la cultura" ${ }^{54}$. En esa línea, el Consejo de Garantías Estatutarias, en su Dictamen 12/2010, de 5 de julio, sobre la prohibición de las corridas de toros en Cataluña ha extraído la conclusión de que: «Desde la lógica de la concurrencia competencial, parece evidente que las concepciones que los diversos poderes públicos puedan tener de aquello que se puede entender como expresión cultural pueden ser comunes y también heterogéneas, e incluso opuestas» (cursivas mías). Y es que, como mías).

53 «La prohibición de las corridas de toros desde una perspectiva constitucional», op. cit., 19 (cursivas

54 La sentencia resolvía un recurso de inconstitucionalidad promovido por la Generalitat contra la Ley 1/1982, de 24 de febrero, por la que se regulaban las salas especiales de exhibición cinematográfica, la filmoteca española y las tarifas de las tasas por licencia de doblaje. Vid. igualmente la STC 11/1986, de 28 de enero, y el comentario al art. 44 de E. NIETO GARRIDO en Comentarios a la Constitución española. XXX Aniversario, María Emilia Casas Baamonde y Miguel Rodríguez-Piñero y Bravo-Ferrer, Madrid, Fundación Wolters Kluwer, 2008, 1083-1087. 
destaca el magistrado José Manuel Bandres Sánchez-Cruzat en su voto particular a la Sentencia del Tribunal Superior de Justicia de Cataluña 854/2001, de 11 de julio, la Ley catalana de protección de los animales de 1988 es «un paradigma cultural de la comunidad de Cataluña». Como expresión de ese paradigma, de esa «cultura» debe entenderse su reforma de 2010 para acabar con las corridas de toros.

\section{4. ¿ESTÁN LOS TOROS EN EL COTO VEDADO CONSTITUCIONAL?: EL ARGUMENTO DE LA IRRELEVANCIA CONSTITUCIONAL DEL BIENESTAR DE LOS ANIMALES}

Finalmente, la tesis que sostiene la inconstitucionalidad de la abolición de las corridas de toros se hace fuerte con la consideración de que con dicha prohibición se sacrifican bienes y derechos constitucionalmente amparados: la libertad de creación artística del art. 20; el derecho a ejercer un oficio u profesión del art. 35 y la libertad de empresa del art. 38. ¿Es inexpugnable esta apelación? A mi juicio no.

$\mathrm{Ni}$ esos derechos invocados, ni la gran mayoría de los derechos fundamentales recogidos en la Constitución, son absolutos, esto es, su sacrificio puede estar justificado ${ }^{55}$. De acuerdo con una muy consolidada doctrina del tribunal constitucional que arranca con la STC 11/1981, de 8 de abril, relativa al derecho de huelga, la existencia de otros derechos en conflicto o de bienes constitucionalmente protegidos, sirven de limitación al alcance de los derechos fundamentales (amén de, obviamente, los propios límites expresamente recogidos en la CE), siempre y cuando dicha afectación sea proporcionada, necesaria e idónea para lograr un fin legítimo y se respete el contenido esencial del derecho afectado ${ }^{56}$.

Así, en la STC 66/1991, de 22 de marzo, el TC tiene que valorar si la Comunidad de Castilla-León, al prohibir la venta de cangrejos de río vulnera los arts. 33.1 (propiedad privada) y 38 de la CE (y con ello la unidad de mercado que antes hemos analizado). Según el Tribunal Constitucional, el fin subyacente a la prohibición —evitar la desaparición del cangrejo autóctono - es constitucionalmente legítimo — está amparado por la protección de los ecosistemas y la utilización racional de los recursos naturales del art. 45.2 CE-y el modo de procurarlo resulta proporcionado (FJ 3$)^{57}$.

¿Es sólo lo explícitamente previsto en la Constitución como Derecho, o bien, o fin lo que puede servir de límite a los derechos fundamentales ${ }^{58}$ ? En uno de los casos clásicos de la jurisprudencia constitucional española en esta materia, la STC 57/1994, de 28 de febrero, se lee: «... los derechos fundamentales reconocidos por la Constitución sólo pueden ceder ante los límites que la propia Constitución expresamente imponga,

55 Recientemente, M. ATIENZA ha sostenido que ninguno de los derechos fundamentales tiene ese carácter; vid. «El caso Gürtel y la objetividad del Derecho», El notario del siglo XXI. Revista del Colegio Notarial de Madrid, núm. 31, mayo-junio 2010, 46-50, 48.

56 Vid. en la misma línea el FJ 8 de la STC 120/1990 (huelga de hambre de los GRAPO).

57 Sobre dicha decisión, y los límites directos e indirectos a la libertad de empresa, remito al estudio monográfico de A. CidonCHA, La libertad de empresa, Madrid, Thomson-Civitas-Instituto de Estudios Económicos, 2006: 275 y ss.

58 Así parece sostenerlo VAQUER, para quien la limitación de la libertad de creación cultural sólo es posible con la moral «constitucionalizada», es decir, con los derechos recogidos en la propia constitución; vid. Estado y cultura, op. cit., 200-207. 
o ante los que de manera mediata o indirecta se infieran de la misma al resultar justificados por la necesidad de preservar otros derechos o bienes jurídicamente protegidos» (FJ 6, cursivas mías) ${ }^{59}$. En este caso, ese bien jurídicamente protegido —el del orden y la seguridad del centro penitenciario- no constituye, a juicio del Tribunal, justificación bastante para la vulneración de la intimidad personal y corporal que suponía la medida ordenada. En otros casos, sin embargo, bienes tales como: la continuidad de los servicios públicos; la intangibilidad de los fondos públicos; la efectividad del principio par conditio creditorum; el uso legítimo de los bienes de dominio público; el ius puniendi del Estado; la dignidad de las Cortes de Aragón o el debido respeto a los órganos y autoridades del Estado, sí han servido como límites al ejercicio de ciertos derechos ${ }^{60}$.

En el caso del derecho al trabajo y a la libre elección de profesión u oficio, son muchas las normas que limitan o incluso impiden el ejercicio de ciertas profesiones y oficios: licencias, títulos profesionales o administrativos, pruebas selectivas previas, colegiación, etc. ${ }^{61}$. También las consideraciones de orden público o ético relativas a la profesión u oficio mismo. En el año 2002 el Comité de Derechos Humanos de la ONU dio la razón al Estado francés en su prohibición de los espectáculos conocidos como «lanzamiento de enanos» (dwarf tossing), no estimando así la reivindicación de su «derecho al trabajo» (recogido en el Pacto Internacional de Derechos Civiles y Políticos) de Manuel Wackenheim, un enano que se empleaba como «proyectil». El orden público francés, alegaba el Consejo de Estado, se ve resentido con eventos que, como el lanzamiento de enanos, ofenden la dignidad humana ${ }^{62}$. Ese mismo tipo de consideraciones son las que abonan la imposibilidad de reconocer la prostitución como un oficio o trabajo en España ${ }^{63}$.

$\mathrm{Si}$, como vengo sosteniendo, el bienestar de los animales es un bien jurídicamente protegido, como muestra el hecho de la tipificación como delito del maltrato a los animales y la existencia de multitud de leyes autonómicas y estatales que prescriben su protección, resulta posible sostener la constitucionalidad del sacrificio de ciertos derechos fundamentales, entre ellos la libertad artística y el libre ejercicio de una profesión u oficio, por parte de la Ley catalana 28/2010. Es cierto que muchos penalistas son reacios a considerar que el bien jurídico protegido en el artículo que castiga el maltrato a los animales sea su bienestar ${ }^{64}$. El legislador penal, sin embargo, parece tenerlo más

59 En juego estaba el alcance del derecho a no sufrir torturas y tratos inhumanos o degradantes y el derecho a la intimidad personal de un preso del centro penitenciario de Nanclares de Oca que había sido sancionado por negarse a realizar unas flexiones tras el cacheo posterior a una comunicación íntima.

${ }^{60}$ He tomado este elenco de G. DOMÉnech PASCuAl, Bienestar animal contra derechos fundamentales, op. cit., 117.

61 Sobre ello, y sobre la jurisprudencia constitucional al respecto, vid. el comentario al art. 35 CE de M. Nogueira Guastavino, en Comentarios a la Constitución española. XXX Aniversario, María Emilia Casas Baamonde y Miguel Rodríguez-Piñero y Bravo Ferrer (dirs.), Madrid, Wolters Kluwer, 2008, 930-948, 937.

62 Communication No. 854/1999, Wackenheim vs. France (15 de julio de 2002).

63 La consideración como ilícita de la prostitución, por ser la causa del contrato contraria a la moral (art. 1275 CC) se encuentra, entre otras, en las sentencias de la Audiencia Provincial de Guipúzcoa de 19 de octubre de 2000, y la Sentencia del Tribunal Superior de Justicia de las Islas Baleares, de 9 de enero de 1992. Estimo, pese a todo, que tanto la resolución del Comité de Derechos Humanos, cuanto la actual negación del carácter laboral de la prostitución, son excesos paternalistas por parte del Estado, y, en ese sentido, están injustificados. La cuestión, sin embargo, excede de los propósitos de este trabajo. Sobre la segunda me remito a mi trabajo: «¿Hacernos los suecos? La prostitución y los límites del Estado», Doxa, 30 (2007): 451-470.

64 Pondré solo dos botones de muestra: M. a MARQUÉS I BANQUE se inclina por considerar nuestras obligaciones de carácter «bioético» como el mejor candidato a engrosar la categoría de bien jurídico protegido por el delito, aunque afirma que la cuestión sigue «abierta»; vid. su comentario al art. 337 en Comentarios al 
claro cuando, en la Exposición de motivos de la Ley Orgánica 5/2010, de 22 de junio, por la que se reforma el Código Penal, dice, al respecto de la nueva redacción del artículo, que la eliminación del requisito del ensañamiento lo es «... al objeto de dotar de una mayor protección a los animales domésticos o amansados frente a los malos tratos que ocasionen su muerte o menoscaben gravemente su salud».

Por otro lado, y como acertadamente ha señalado DOMÉNECH, del hecho de que la limitación de un derecho fundamental es lícita cuando así se protege un bien constitucional, no se sigue que sean ilícitas las que protejan bienes no constitucionalmente consagrados ${ }^{65}$. La cuestión clave radica, para él, en si la medida en cuestión resulta proporcional, necesaria e idónea. Y su respuesta es, en relación con las corridas de toros, que no: la medida no es proporcional, pues, siendo el fin legítimo, carece de rango constitucional, y el beneficio - unos 96 toros al año que dejarían de sufrir en la plaza- palidece frente a los costes empresariales y ambientales y de pérdida de libertades de «muchas más de 96 personas». Todo lo cual impide considerar que la medida sea conforme con la Constitución ${ }^{66}$. Junto a ello, DOMÉNECH considera que hay un vicio de arbitrariedad por incoherencia en la prohibición, pues son otras las medidas que se deben adoptar antes, dado el fin propuesto de acabar con el sufrimiento de los animales.

Los juicios de proporcionalidad como el que sumariamente practica DOMÉNECH, siguen sólo metafóricamente una lógica contable. No es que no dispongamos de métrica para la pérdida de libertad o la frustración de la preferencia de ir a las corridas de toros, es que carecemos, para empezar, de una magnitud cardinal. Otras magnitudes - los costes económicos del sector- asumo que son mensurables, pero se me escapa su comparación con los daños — ciertamente cuantificables- que suponen en el animal: litros de sangre, centímetros de heridas, músculos rotos, cordones medulares seccionados, acidosis por insuficiencia respiratoria, alteraciones hormonales, reducciones drásticas de las presiones parciales del oxígeno por el esfuerzo, úlceras de córnea, desprendimientos de retina, bajos niveles de potasio y sodio reveladores del agotamiento de la glándula suprarrenal que libera cortisol y aldosterona para paliar el estrés y otros parámetros objetivables. En la anterior balanza metafórica deben colocarse también las preferencias, angustias y pesar de los miles de individuos, catalanes o no, que albergan un sentimiento de compasión y solidaridad por el sufrimiento de mamíferos superiores. Igualmente, las compensaciones económicas previstas «a los titulares de derechos subjetivos afectados» que recoge la Disposición Adicional Primera de la Ley 28/2010. Y tampoco puede olvidarse — cosa que DOMÉNECH no hace-el carácter pú-

Código Penal (t. III), Gonzalo Quintero Olivares (dir.), Cizur Menor, Thomson-Aranzadi, 2008, 173-181, 177. C. Conde-PumPido y J. López BARJA DE Quiroga, consideran que es la colectividad o un interés difuso o general de que no se produzcan maltratos a los animales, porque con ello se atenta contra sentimientos humanos, lo que conforma el bien jurídico; vid. su comentario al art. 337 en Comentarios al Código Penal, Cándido Conde-Pumpido (dir.), Barcelona, Bosch, 2007, 2573-2579, 2575.

${ }_{65} \mathrm{Ibid}$., 114. En la jurisprudencia alemana, y en relación con el bienestar de los animales, cabe encontrar un patrón parecido: hay fines que el legislador puede legítimamente perseguir, aunque erosionen ciertas libertades constitucionalmente protegidas. La libertad profesional o empresarial de quien se dedica a la producción de huevos y desea reducir al mínimo las dimensiones de las jaulas de las gallinas ponedoras, o la de quien desea amputar partes del cuerpo de un animal se ve limitada por el bienestar de éstos. También la libertad artística de quien decapita a una gallina embadurnándose con su sangre para así protestar por la violación de los derechos humanos; id., 96-97.

66 «La prohibición de las corridas de toros...», op. cit., $24-27$. 
blico de las corridas: los perniciosos efectos colectivos que genera la exhibición y celebración de la crueldad humana, la inmisericordia, la falta de empatía y otros vicios que conforman la peor faz de nuestra condición ${ }^{67}$. Ese carácter, junto con la importancia social que reviste la tradición de las corridas, y el hecho de que con su celebración no se satisfagan derechos básicos de los seres humanos - a diferencia de otras prácticas que también generan sacrificio al bienestar animal, pero con las que obtenemos beneficios tangibles para colmar necesidades primarias, como en el caso de la experimentación biomédica- permite superar la objeción de ser la medida arbitraria o incoherente.

Cataluña ha mantenido - con el pésimo argumento de la tradición — una práctica -el corre bous - moralmente censurable aunque no cause la muerte del animal, y lo ha hecho insistiendo en que su pervivencia se restringe a los lugares y en los momentos donde se venían celebrando y quedando prohibido causar daños a los animales (art. 2 de la Ley 28/2010). Por otro lado, no hubiera podido modificar las corridas de toros para impedir el sufrimiento que se produce en las suertes de varas y banderillas, así como su muerte (con artes como la puntilla que están prohibidas en la actual normativa reguladora del sacrificio de animales) ${ }^{68}$ pues con ello habría asumido competencias en esa materia de ordenación del festejo que no le corresponden de acuerdo con la Ley 10/1991, de 4 de abril, sobre potestades administrativas en materia de espectáculos taurinos y la normativa general que ya hemos tenido oportunidad de analizar. En este punto me atrevo a afirmar que estamos ante un caso en el que no se cumple el a maoire ad minus: Cataluña no puede lo menos — variar la forma en que se celebran las corridas de toros- pero sí puede lo más — prohibirlas-.

Finalmente, que haya otras actividades que, por implicar un gran sufrimiento a los animales, sean también censurables, no convierte a la prohibición de las corridas de toros en algo arbitrario, ni mucho menos las hace permisibles o legítimas ${ }^{69}$. Utilizando una imagen feliz — aunque grosera- de J. MosTERÍN, las corridas de toros son el trozo de mierda en la cara del politraumatizado que llega al hospital tras un accidente. Recomponer sus huesos es lo más importante, pero no cuesta nada, camino del quirófano, limpiarle el cutis ${ }^{70}$. No es tan claro además, por seguir con el ejemplo, que, como esgrime DOMÉNECH, la caza y la pesca sean las fracturas de los huesos que haya que reducir

${ }^{67}$ Así lo ha reconocido muy recientemente el Tribunal Superior de Justicia de Madrid en la Sentencia 924/2005, de 26 de octubre (JUR 2006/67242). Se trataba de un recurso interpuesto por los organizadores de un festejo taurino en la Feria «Ibertoro» de Madrid, contra la Dirección General de Turismo de la Comunidad Autónoma de Madrid que había negado la autorización a su celebración por ser contrario al Reglamento de Espectáculos Taurinos de la Comunidad de Madrid (Decreto 112/1996, de 25 de julio). De acuerdo con el tribunal, los espectáculos propuestos (el «Concurso-Faena de Tientas» y la exhibición de rejones a la usanza portuguesa) no se encuentran regulados en aquella normativa, con lo que resulta de aplicación lo que dispone la Ley 17/97, de 4 de julio, de la Comunidad Autónoma de Madrid de espectáculos públicos y actividades recreativas, que prohíbe la «celebración de espectáculos que impliquen crueldad o maltrato para los animales, les pueda ocasionar sufrimiento o hacerles objeto de tratamientos antinaturales». De acuerdo con el tribunal, siendo posible y necesario (y «carente de reproche moral o jurídico») el uso de la puya de tentar en las pruebas con las que se valora la bravura del toro en las fincas ganaderas, uso que supone infligir heridas sangrantes al toro, la exhibición pública de tales pruebas, más allá del ámbito privado, «... adquiere otra dimensión» que las hace merecedoras de ser incluidas entre los espectáculos prohibidos (FJ 6).

68 El Reglamento 1099/2009 del Consejo, de 24 de septiembre de 2009, relativo a la protección de los animales en el momento de la matanza, prohíbe la puntilla como «método de sujeción» [art. 15.3.c)].

69 «La prohibición de las corridas...», op. cit., 25 y ss.

70 «Ese trozo de mierda en la cara», El País, 12 de septiembre de 1991. 
en primer lugar. Por todas las razones anteriores — relativas a la mensurabilidad del sufrimiento, que en el caso de los toros, insisto, es atroz, y por su carácter público-y porque, en este caso, la decisión ha contado con un respaldo social amplísimo.

Pero supongamos que todo mi esfuerzo argumentativo es en vano, que es cierta la tesis defendida por T.-R. FERNÁNDEZ, cuya principal consecuencia es que una iniciativa no ya del poder autonómico, sino del parlamento estatal, con la que se quisieran prohibir las corridas de toros exigiría la previa reforma de la Constitución. Incluso si, como ha ocurrido en Cataluña, el catalizador de dicha medida hubiera sido una iniciativa legislativa popular ampliamente respaldada. Esta tesis me parece descabellada (con perdón, dado el contexto), pero es muy importante determinar por qué. A ello me dispongo para finalizar.

Parafraseando la feliz imagen de J. CERCAS en Anatomía de un instante, toda Constitución tiene su placenta, es decir, un conjunto de circunstancias coyunturales que nutrieron su contenido: no es extraño que, en la Constitución española, junto con la justicia, la igualdad y la libertad figure el «pluralismo político» como uno de los valores superiores del ordenamiento, como no puede sorprender que en la Constitución alemana la cláusula de la dignidad del ser humano del art. 1.1 sea irreformable ${ }^{71}$. Ni el bienestar ni la protección de los animales, en general, ni las corridas de toros en particular, estuvieron, ni pudieron estar, en la agenda del constituyente español, afanado por crear los mimbres de un sistema democrático y por hacer efectivos ciertos derechos y libertades de los individuos que son miembros de la especie Homo sapiens. Esas eran las urgencias entonces.

Pero la placenta constitucional española, como las placentas en general, no deben impedir el desarrollo y progreso de la criatura que han venido alimentando, ni sus nuevas aspiraciones ni reivindicaciones. La protección de los animales, junto con otras muchas demandas, es una de ellas. Los tópicos de la dogmática constitucional tales como «apertura constitucional»; «constitución como marco» $\mathrm{u}$ «organismo vivo», comparten el común denominador de que se ha de leer, interpretar y aplicar el texto constitucional haciendo abstracción del contexto en el que se dio para así facilitar a las nuevas generaciones su desenvolvimiento político ${ }^{72}$.

También hay una «placenta genérica» del hecho constitucional: garantizar ciertos derechos frente al procedimiento mayoritario para así satisfacer bienes «primarios» de los individuos, según la célebre definición de «coto vedado» de E. GARZÓN VALDÉS ${ }^{73}$. La Constitución española muestra esa «placenta genérica» cuando, por ejemplo, prohíbe la tortura (art. $15 \mathrm{CE}$ ) o impide la privación de nacionalidad a los españoles de origen

71 Estamos necesitados, sin embargo, de saber qué coyuntura llevó a la mayoría de los ciudadanos del Estado de Florida a introducir la enmienda que prohíbe la estabulación de las cerdas embarazadas (vid. supra nota 4).

72 Bajo estos parámetros se pronuncia el magistrado Humberto Antonio Sierra Porto en su voto particular a la Sentencia de la Corte Constitucional colombiana C-1192/2005. Las corridas de toros son una práctica social permitida pero, con el expediente de su incorporación al patrimonio cultural intangible necesariamente defendido por el Estado, no pueden parapetarse constitucionalmente cuando hay una fuerte controversia social sobre su moralidad. Es al legislador a quien en su caso corresponderá, de acuerdo con ese sentir social, mantenerlas o proscribirlas.

73 «Representación y democracia», en Derecho, ética y política, Madrid, Centro de Estudios Constitucionales, 1993. 
(art. 11.2 CE), o cuando establece que los españoles son mayores de edad a los dieciocho años (art. 12) o que el Congreso es elegido por cuatro años (art. 68.4). Pero junto a ello también se prescribe que la bandera de España es roja, amarilla y roja, siendo la banda amarilla del doble de anchura que cada una de las rojas (art. 4.1) o que se prefiere al varón en la línea sucesoria a la Corona (art. 57.1). Además de garantizar bienes y derechos fundamentales del ser humano, la Constitución aporta una solución estable a ciertos problemas de coordinación mediante normas secundarias - moralmente inocuas por ser meras especificaciones de fines y valores subyacentes-y crea ciertos símbolos.

El problema de la legitimidad y fundamento de estos atrincheramientos, como en general de la rigidez de los textos constitucionales, es bien conocido y discutido - y no es el objeto de mi interés prioritario ahora-. El hecho es que tales atrincheramientos tienen un resultado sospechoso: hacer casi imposible — aun en grados distintos— dictar normas que alteren o anulen dichos preceptos constitucionales. Modificar la anchura de la franja amarilla de la bandera española es tan costoso en términos procedimentales como acabar con la injusta preferencia del varón de la injusta institución monárquica (art. $168 \mathrm{CE}$ ), lo cual no deja de resultar llamativo. Como también resultaría a mi juicio muy chocante que, para acabar con un espectáculo popular que genera tanto sufrimiento a seres sintientes y concita tanta repulsión universal como las corridas de toros, hubiera que reformar previamente la Constitución. Y además por la vía procedimentalmente más exigente. Los constituyentes españoles no pudieron anticiparse en 1978 a un sentimiento o inclinación ética a favor de otorgar, al menos a algunos animales, un cierto estatuto moral, pero tampoco les fue dado entretenerse en el blindaje de la tradición cultural taurina. Hubiera sido una frivolidad frente a las muchas otras prioridades entonces golpeando la puerta constitucional; hubiera sido además un ataque frontal a la libertad colectiva de autogobierno de las generaciones futuras. Es por ello por lo que, también la placenta constitucional «genérica» debe verse recelosamente a la luz del valor de la democracia, es decir, del derecho de todos a participar en la toma de decisiones que nos afectan. Las corridas de toros no están constitucionalmente prohibidas, pero tampoco lo está su prohibición. La constitución española guarda un respetuoso silencio sobre la materia, silencio que se ha de interpretar como estruendoso si es que una mayoría, como ha ocurrido, decide clamar para que se abolan.

Ello no impide predicar que hay casos «constitucionalmente claros». El art. 159.3 de la Constitución española establece que los magistrados «serán designados por un periodo de nueve años». Mediante la reforma operada por la Ley Orgánica 8/2010 de 4 de noviembre ( $B O E$ de 5 de noviembre), en el art. 16 de la Ley Orgánica del Tribunal Constitucional se añade un apartado en el que se establece que: «Si hubiese retraso en la renovación por tercios de los Magistrados, a los nuevos que fuesen designados se les restará del mandato el tiempo de retraso en la renovación». Es decir, aquellos que sustituyan a quienes ocuparon su cargo, pongamos, tres años más por no haber sido renovados a tiempo, serán designados por un periodo de seis años y no nueve como establece la Constitución.

¿Es esta inconstitucionalidad del art. 2 de la Ley 8/2010, de 4 de noviembre, equiparable a la, en palabras de T.-R. FERNÁNDEZ, «radical inconstitucionalidad» de la prohibición de las corridas de toros en Cataluña? Mi tesis es que no, que la segunda no lo es tanto (o la primera lo es mucho más) y que, cuando aquél no es el caso, es decir, 
cuando no estamos ante una inconstitucionalidad flagrante, las circunstancias democráticas que han rodeado la decisión deben pesar como un factor decisivo para inclinar la balanza a favor de la constitucionalidad de la medida. Se trata de la aplicación de la conocida como «regla Thayer» o de presunción de constitucionalidad de la ley ${ }^{74}$, una de las llamadas por ALEXY, «cargas de la argumentación» del juicio de proporcionalidad cuando la situación es de equilibrio o empate. Pues bien: ¿en qué contexto se ha producido la decisión de abolir las corridas y bajo qué procedimiento se ha hecho?

La prohibición de las corridas de toros en Cataluña, como estación final de un largo recorrido previo, no puede sorprender a nadie. Como se ha señalado ya reiteradamente, en la primigenia ley catalana de protección de los animales se prohibía la construcción de nuevas plazas de toros, y en la posterior de 2003 se limitó el acceso a los menores de catorce años. En 1989 Tossa de Mar (Girona) se erigía como primer municipio «antitaurino», movimiento al que, a día de hoy, se han sumado 84 municipios más, entre ellos la propia Barcelona, donde ya venían siendo muy escasos los festejos taurinos ${ }^{75}$. De acuerdo con los datos del anuario del Ministerio del Interior correspondientes al año 2009, todas las corridas de toros celebradas en Cataluña tuvieron lugar en Barcelona (14), lo cual contrasta significativamente con las celebradas en Andalucía (153), Castilla-La Mancha (91) o la Comunidad de Madrid (100) ${ }^{76}$. Así y todo, en prácticamente todas las CC.AA. hay un descenso notable del número de festejos (en Murcia, donde se produce la más notable reducción, un 43 por 100 menos, y en total un 15 por 100 menos). En la edición de La Vanguardia de 14 de marzo de 2010, se publicaba una encuesta de acuerdo con la cual el 43 por 100 de los catalanes está a favor de la prohibición, frente a un 36 por 100.

Cataluña es ciertamente singular en esta materia, pero el declive en el aprecio al festejo taurino y el incremento de sus detractores también se produce en el resto del Estado. De acuerdo con los datos de la encuesta Gallup, en el año 1971 un 55 por 100 de los españoles mostraba interés por los festejos taurinos. En octubre de 2006 esa cifra era del 27 por 100. Los más interesados son los mayores de sesenta y cuatro años (41 por 100) frente al 18 por 100 de los menores de veinticinco años ${ }^{77}$.

La prohibición de las corridas en Cataluña es el resultado de una iniciativa legislativa popular promovida por la plataforma PROU que logró, en tres meses, más de 180.000 firmas (la Ley 1/2006, de 16 de febrero, exige 50.000). La tramitación parlamentaria de la iniciativa se inició el 21 de julio de 2009 y el 18 de diciembre de ese mismo año se produjo el debate a la totalidad de la proposición de ley en el Pleno, votación que arrojó el resultado favorable a que el Parlament prosiguiera con la discusión y eventual aprobación de aquella. Durante el trámite en la Comissió de Medi Ambiente y Habitatge comparecieron treinta expertos — quince en representación de cada una de las dos

74 Sobre la misma y su alcance, vid. mi trabajo: «Justicia constitucional y deferencia al legislador», en Constitución: problemas filosóficos, F. Laporta (ed.), Madrid, Centro de Estudios Políticos y Constitucionales, 2003, 345-370 (antes en «La posibilidad del constitucional thayeriano», Doxa, 23 (2000): 49-75).

${ }^{75} \mathrm{La}$ declaración es, con todo, puramente simbólica pues las corporaciones locales no tienen competencia para adoptar esa medida. También Castrillón (Asturias) y Coslada (Madrid) se han declarado municipios antitaurinos.

$76 \mathrm{Vid}$. http://www.mir.es/SGACAVT/juegosyespec/toros/estadistica/EstadxsticasTaurinas2009.pdf.

77 Los datos de la encuesta fueron publicados por el diario El País, en su edición de 18 de diciembre de 2006 (47). 
posiciones- durante el mes de marzo de 2010. Con carácter previo a la votación final en el pleno, el Consejo de Garantías Estatutarias de la Generalitat dictaminó el 6 de julio de 2010 - a salvo del voto particular del consejero Julio Añoveros Trias de Besque la proposición era acorde con la Constitución española y el Estatut de Cataluña.

\section{CONCLUSIÓN: LA CONSTITUCIONALIDAD \\ DE LA PROHIBICIÓN DE LAS CORRIDAS DE TOROS COMO UN CASO DE «CONSTITUCIONALIDAD ATÍPICA»}

Para entender las figuras del abuso del Derecho, el fraude de ley y la desviación de poder, M. ATIENZA y J. RuIZ MANERO han propuesto un sugerente modelo del que me voy a servir como refuerzo de la tesis que vengo sosteniendo. ATIENZA y RUIZ MANERO consideran que hay conductas prima facie prohibidas, que, a la luz de ciertos principios relevantes del sistema jurídico, resultan permitidas: se trata de los «lícitos atípicos». Habría, según ellos, tres categorías de licitud atípica: la que deriva del hecho de que la conducta cae «fuera del alcance» de la regla prohibitiva, porque las razones a favor de esta regla no se dan en un caso concreto; la que resulta de considerar una razón que se da en el caso que es más poderosa que las tenidas en cuenta al promulgar la regla, y que no fue contemplada por quien la dictó (supuestos de «excepción»); y la que es consecuencia del hecho de que con la conducta se afecta el bien jurídico, o se frustra el propósito perseguido por la autoridad normativa, en grado mínimo (principio de tolerancia) ${ }^{78}$.

De igual forma, habría constitucionalidades atípicas, esto es, conductas del legislador (la promulgación de una norma) que podrían entenderse prima facie prohibidas (por inconstitucionales), pero que, a la luz de la existencia de razones no tenidas en cuenta y que son de aplicación al caso, permiten sostener su carácter constitucional. Ese es el caso de la prohibición de las corridas de toros en Cataluña. Todas las autoridades ponderan, de acuerdo con la tesis de ATIENZA y Ruiz MANERO: tanto el legislador, como el juez, y, como he de añadir yo ahora, el constituyente. En el caso del bienestar de los animales, por las razones «placentarias» antes señaladas, al constituyente español no le fue dado siquiera ponderar. El legislador catalán, sin embargo, ha tenido la oportunidad de abordar un asunto sensible, política y moralmente, en un modo muy encomiable desde el punto de vista del ideal democrático. Y al juez constitucional, ahora, le tocará también ponderar. Yo espero que lo haga teniendo en cuenta esas «nuevas» circunstancias no antes vislumbradas - la sensibilidad y concienciación que ha despertado el conocimiento de las muchas semejanzas que tenemos todos los mamíferos superiores y el sufrimiento gratuito que les causamos - y también la calidad deliberativa que ha adornado la decisión. Y espero que lo haga teniendo en cuenta el bienestar futuro de esos animales que dejarán de ser torturados públicamente. De ello dependerá también la suerte de la Constitución misma: que aparezca o no como un organismo maduro, adaptado, que permite que el cambio y progreso social discurra por los cauces de la democracia.

78 Vid. Ilícitos atípicos, Madrid, Trotta, 2006: 115 y ss. 